\title{
Expressões, características e perspectivas do Cristianismo da Libertação
}

\section{Expressions, Characteristics and Perspectives of Liberation Christianity}

\section{Expresiones, características y perspectivas del cristianismo de la liberación}

\author{
iD (9) Fabio Lanza \\ Universidade Estadual de Londrina, Londrina, Paraná, Brasil \\ lanza1975@gmail.com \\ (iD) Luis Gustavo Patrocino \\ Universidade Estadual Paulista, Marília, São Paulo, Brasil \\ patrocinolg@gmail.com \\ iD Lenir Cândida de Assis \\ Universidade Estadual de Londrina, Londrina, Paraná, Brasil \\ lenirassis@sercomtel.com.br
}

Resumo: O trabalho de pesquisa teve origem no $14^{\circ}$ Intereclesial das Comunidades Eclesiais de Base, ocorrido em Londrina - Paraná, em janeiro de 2018, e objetivou identificar se há expressões do Cristianismo da Libertação na sociedade brasileira do século XXI, perceber as relações entre as diretrizes do papa Francisco e os encaminhamentos elaborados no evento, assim como caracterizar as perspectivas expressadas pelos sujeitos diante do contexto brasileiro contemporâneo. As fontes da investigação são documentais e os dados foram coletados por meio de 2.137 questionários respondidos pelos participantes do evento. Evidenciou-se que há uma perspectiva política progressista em relação ao contexto atual (século XXI) no Brasil, com a adoção de encaminhamentos focados no coletivo e no social, indicação da urgência das ações civis dos católicos presentes nos mecanismos de participação democrática e popular na luta pela justiça, na defesa dos direitos e na garantia do acesso às cidades, com o fortalecimento das políticas públicas.

Palavras-chave: Cristianismo da Libertação. $14^{\circ}$ Intereclesial das Comunidades Eclesiais de Base. Encíclica Laudato Si'. Sociologia das Religiões. 
Abstract: The research work came from the 14th Inter-Church of the CEBs, which took place in Londrina - Paraná, in January 2018 and aimed to identify if there are expressions of Liberation Christianity in the 21st century Brazilian Society, as well as understand the relationship between pope Francis guidelines and the referrals elaborated at the event and characterize the perspectives expressed by the subjects in the contemporary Brazilian context. The sources of the investigation are documents and data collected through 2,137 questionnaires answered by event attendees. It evidenced that there is a progressive political perspective in face of the current context of the 21st century in Brazil, adopting referrals with collective and social emphasis, indicating the urgency of the civil actions of Catholics present in the mechanisms of democratic and popular participation, in the fight for justice, in the defense of rights and in guaranteeing access to cities, with the strengthening of public policies.

Keywords: Liberation Christianity. $14^{\circ}$ Intereclesial das Comunidades Eclesiais de Base. Encyclical Laudato Si '. Sociology of Religions.

Resumen: El trabajo de investigación provinó de la 14ª Inter-Iglesia de las Comunidades Eclesiales Básicas, ocurrido en Londrina - Paraná, en enero de 2018 y apuntó a identificar si hay expresiones del cristianismo de la liberación en la sociedad brasileña del siglo XXI, bien como, comprender las relaciones entre las pautas del papa Francisco y las referencias preparadas en el evento y caracterizar las perspectivas expresadas por los sujetos delante del contexto brasileño contemporáneo. Las fuentes de investigación son documentales y datos recolectados a través de 2,137 cuestionarios respondidos por los participantes del evento. Se evidenció que existe una perspectiva política progresiva frente al contexto actual del siglo XXI en Brasil, adoptando referencias con énfasis colectivo y social, indicación de la urgencia de las acciones civiles de los católicos presentes en los mecanismos de participación democrática y popular, en la lucha por la justicia, en la defensa de los derechos y en la garantía del acceso a las ciudades mediante el fortalecimiento de las políticas públicas

Palabras clave: Cristianismo de la liberación. $14^{\circ}$ Inter-Iglesia de las Comunidades Eclesiales Básicas. Encíclica Laudato Si'. Sociología de las religiones.

Data de recebimento: 31/07/2019

Data de aceite: 29/09/2019 


\section{Introdução e cuidados epistemológicos}

Quando tentamos compreender nosso habitat existencial, precisamos buscar conhecer os contextos histórico-sociais, bem como os atores desse processo que descortinamos. Neste texto objetivamos analisar, no Brasil do início do século XXI, as características sociais e as perspectivas que podem aprimorar a formação da sociedade brasileira pelo prisma de um regime democrático com maior qualidade. Também visamos aos aspectos que podem produzir melhorias nos serviços públicos prestados à população em geral. Para isso, é necessário investir tempo e esforços que elucidem certas relações sociais existentes. A partir de contribuições da Sociologia das Religiões, focaremos as conexões existentes entre o campo católico brasileiro, parte de suas organizações e seus líderes religiosos, e, por último, suas interfaces com as políticas públicas brasileiras e a atual encíclica do papa Francisco (2015).

De forma específica e com a intencionalidade descrita, trataremos de um segmento católico, e de sua abordagem política, econômica, social e religiosa, o Cristianismo da Libertação atuante desde a década de 1970 e os Encontros das Comunidades Eclesiais de Base (CEBs). Nosso recorte privilegiou o $14^{\circ}$ Intereclesial ocorrido em Londrina, no estado do Paraná, em janeiro de 2018. Os intereclesiais das CEBs são encontros periódicos que reúnem representantes de diversas pastorais, organismos e serviços da Igreja Católica, representados por bispos, padres, religiosos(as), mas predominantemente leigos(as) de todos os estados brasileiros.

Os Intereclesiais possuem um caráter ecumênico e desses encontros participam outras denominações religiosas. Eles apresentam como singularidade uma manifestação pública de ações referentes à população pobre e marginalizada, vinculando à devoção católica uma externalização política das crenças visando a intervenções no âmbito do Estado e da sociedade. As CEBs, na atualidade, ainda mantém um vínculo estreito com a proposta da Teologia da Libertação e dissemina suas práticas religiosas con- 
Expressões, características e perspectivas do Cristianismo da Libertação

Fabio Lanza • Luis Gustavo Patrocino • Lenir Cândida de Assis

frontando-se no processo histórico com outras perspectivas internas da própria Igreja Católica.

Primeiramente, é necessário distinguir os conceitos básicos que envolvem os sujeitos pesquisados e os dados que serão apresentados a seguir. Para Löwy, a Teologia da Libertação (TDL) é assim definida:

\begin{abstract}
Herdeira dessa tradição católica, a teologia da libertação inova modernizando-a: a) ao radicalizá-la e ao generalizá-la para todo o capitalismo; b) ao juntar à leitura moral do capitalismo uma análise econômica; c) ao passar do conceito de caridade ao de justiça social; d) ao não valorizar um modelo passado, mas promover uma caminhada para o futuro (utopia social). Seria, pois, um erro grosseiro querer explicar unicamente por influência do marxismo a hostilidade da teologia da libertação (ou dos bispos que lhe são chegados) à ordem econômica existente. A sua rejeição ao espírito do capitalismo é antes de tudo ética e remonta às fontes antigas e pré-modernas da cultura católica - o que a torna muito mais intransigente do que a de muitas correntes marxistas. (LÖWY, 1989, p. 51).
\end{abstract}

Essa definição conceitual, que destaca aspectos da tradição católica pré-moderna, é de fundamental importância para distinguir a TDL dos clichês produzidos e amplamente difundidos que tecem críticas e a estreitam sob uma perspectiva econômica, esvaziando os demais aspectos constituidores da TDL. Outra distinção importante a ser realizada diz respeito às diferenças entre Teologia da Libertação e o movimento do Cristianismo da Libertação:

Mais exatamente, ela [TDL] é a expressão - enquanto sistema coerente de valores e idéias - de todo um movimento social que atravessa a Igreja e a sociedade, a que se poderia chamar Igreja dos pobres ou cristianismo da libertação. Esse movimento apresenta-se como uma ampla rede informal, uma corrente vasta e diversificada de renovação religiosa, cultural e 
política, presente tanto "na base", nas comunidades, paróquias, associações de bairros, sindicatos, ligas camponesas, como na "cúpula", nos bispados, nas comissões pastorais, conferências episcopais nacionais ou regionais. Por razões que ainda estão por determinar, esse movimento social desempenha um papel determinante na Igreja e/ou no "povo cristão" de certos países - principalmente no Brasil, no Peru e na América Central - ao passo que noutros (como a Argentina e a Colômbia) é bastante minoritário, senão isolado. Em todo caso, transtornou muito profundamente uma Igreja que foi, durante séculos, segundo a expressão de Gutierrez, "uma peça do sistema”, uma força de legitimação da ordem social vigente [...] (LÖWY, 1989, p. 58).

Por essa perspectiva teórica, compreendemos que a vivência e a produção decorrente dos Encontros das Comunidades Eclesiais de Base - CEBs são partes do amplo movimento do Cristianismo da Libertação. Dessa forma, apresentam-se na historicidade nacional como um vetor cujo sentido se antagoniza no momento de seu surgimento, quando a Guerra Fria e a ditadura militar (1964-1985) impunham ao mundo e ao país uma relação forte e estreita com um conjunto de ideias norte-americanizado, especialmente vinculado com a defesa do capitalismo ocidental. Na conjuntura atual, como exporemos, continuam antagonizando a crescente onda de conservadorismos, que faz pedidos de intervenção militar e acredita que as Forças Armadas Brasileiras seriam as solucionadoras dos entraves econômicos e da crise política brasileira.

O século XXI exigiu que as Ciências Humanas e Sociais debatessem o contexto e as propostas dos diferentes grupos e partidos conservadores na Europa e na América. Nesse sentido,

o tema da luta contra a corrupção não é específico da extremadireita, mas tem sido demagogicamente manipulado, com certo sucesso, por setores conservadores, na Europa e, sobretudo, no Brasil. No Brasil é uma velha tradição, desde os anos 1940, dos conservadores: levanta-se a bandeira do combate à corrupção 
para justificar o poder das oligarquias tradicionais e, segundo o caso, legitimar golpes militares. 4) O que é comparável na extrema-direita francesa e brasileira são dois temas de agitação sociocultural do conservadorismo mais reacionário: I. A ideologia repressiva, o culto da violência policial, o chamado a restabelecer a pena de morte: é o caso na Europa da extrema-direita e no Brasil da "bancada da bala", fortemente representada no Congresso. II. A intolerância com as minorias sexuais, em particular os homossexuais, é um tema agitado, com certo sucesso, por setores religiosos, com referência católica (Opus Dei, Civitas etc.) na França e evangélica neopentecostal no Brasil. 5) O elemento mais preocupante da extrema-direita conservadora no Brasil, que não tem um equivalente direto na Europa, é o apelo aos militares. O chamado a uma intervenção militar, o saudosismo da ditadura militar, é sem dúvida o aspecto mais sinistro e perigoso da recente agitação de rua conservadora no Brasil, ativamente promovido pelo PIG, o Partido da Imprensa Golpista. (LÖWY, 2015, p. 662-3).

Ao considerarmos que alguns segmentos católicos estiveram (ou ainda estão) associados aos grupos políticos conservadores na Europa e na América, e sabendo da ação estratégica institucional de minorar o poder dos principais clérigos adeptos da TDL no Brasil, elaboramos os seguintes problemas que nortearam a escrita: O cerceamento dos Teólogos Católicos da Libertação entre 1978 e 2013, pontificados de João Paulo II e Bento XVI, foi o fim do Cristianismo da Libertação no Brasil? Ainda existem expressões do Cristianismo da Libertação na sociedade brasileira do século XXI?

As reflexões expostas também permitem problematizarmos: As propostas e encaminhamentos do $14^{\circ}$ Intereclesial das CEBs estão alinhados com quais perspectivas no contexto brasileiro? Quais são as ações e os encaminhamentos que os participantes buscam multiplicar pelo Brasil em suas comunidades? Tais aspectos serão apresentados na terceira seção deste trabalho. 


\section{Características do perfil dos participantes do $14^{\circ}$ Intere- clesial}

As CEBs no Brasil organizam seus encontros Intereclesiais desde 1975. Sempre houve rodízio na cidade sede (exceto no surgimento, quando ocorreram dois encontros em Vitória-ES). Ainda assim, pode-se notar que as edições do evento não se limitam a uma regionalidade determinada. No que concerne à periodicidade, não é possível identificar uma média constante. As datas dos eventos não seguem um padrão. Na Figura 1, percebe-se que o número de participantes tem se mantido constante nos últimos 20 anos.

Figura 1 - Quantitativo das participações dos encontros Intereclesiais de 1975 a 2018

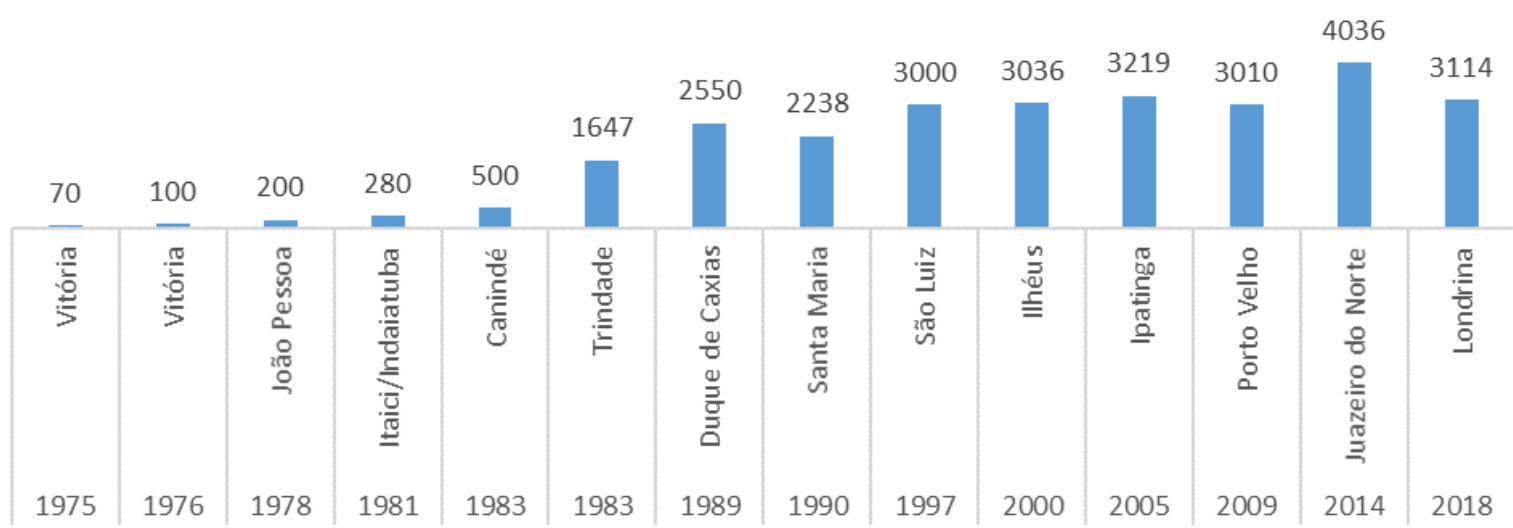

Fonte: CNBB (2018) e Pesquisa sobre o $14^{\circ}$ Intereclesial das CEBs em Londrina, PR (2018).

Tendo, como média, 1928 participantes ao longo de todos os eventos, nota-se que, a partir de 1997 o número de participantes começa a ser significativamente ${ }^{1}$ superior. Ao recortarmos esses últimos 21 anos (1997 a 2018), temos uma média de 3235 participantes, apenas em 2014, em Juazeiro do Norte, houve uma

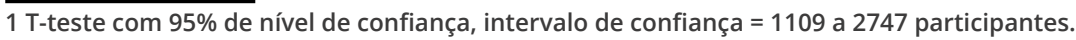


Expressões, características e perspectivas do Cristianismo da Libertação Fabio Lanza • Luis Gustavo Patrocino • Lenir Cândida de Assis

variação significativa ${ }^{2}$ de participações. Ainda assim, a quantidade de participantes é muito próxima do limite superior do intervalo. Essas informações nos permitem afirmar a existência de uma adesão estável a esse evento durante as últimas décadas. Se essa constância também ocorrer nas ações dos indivíduos, podemos ter um componente importante na compreensão do campo católico no País.

Na Figura 2, apresenta-se a taxa de variação das populações religiosas no Brasil ponderadas pela taxa de crescimento populacional em relação ao Censo anterior, assim é possível notar o quanto cada instituição variou em número de adeptos entre os Censos, mas vinculando esse acréscimo à variação populacional. Percebemos, então, que, embora o número de adeptos possa ter aumentado em relação ao crescimento populacional, ele pode ter perdido significância. No que se refere aos catolicismos, notamos, assim como Neri (2011, p. 6), um decréscimo constante de adeptos, que se acentua a partir de 1980.

Figura 2 - Taxas de variação populacional religiosa entre Censos das religiões no Brasil

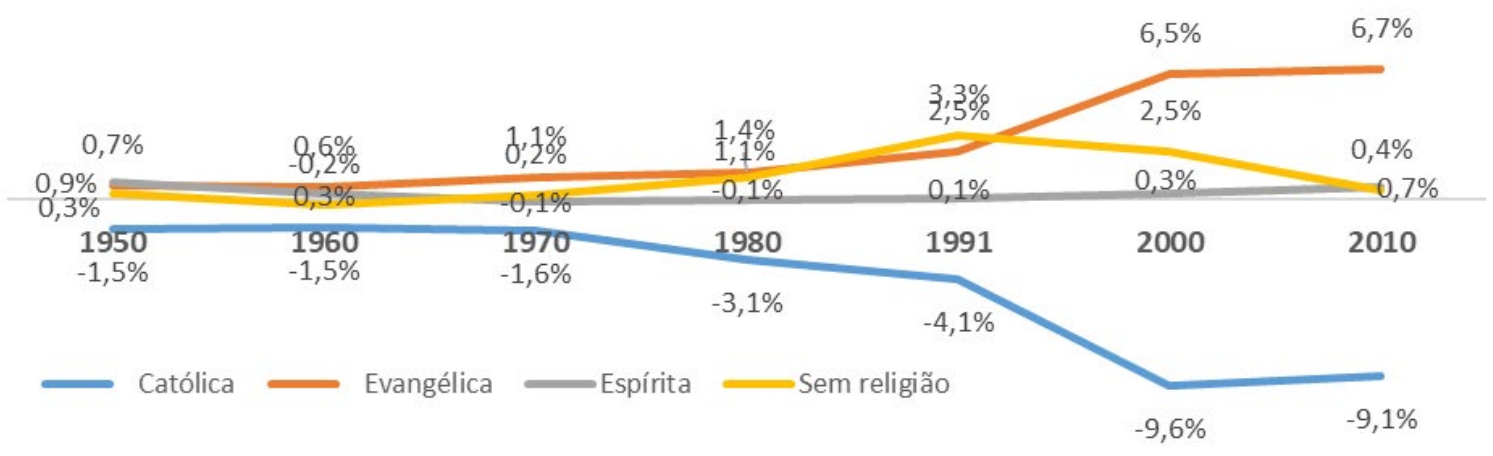

Fonte: IBGE, série histórica pop060. Instituto de Pesquisa Econômica Aplicada (2014).

Nota: O gráfico é uma adaptação das duas tabelas citadas e ajusta a taxa de crescimento numérico em relação ao crescimento da população. Dessa forma, os valores percentuais de crescimento religioso referenciam a quantidade populacional levantada pelos censos dos respectivos anos.

Com a realização do $14^{\circ}$ Intereclesial na região sul, o Laboratório de Estudos sobre Religiões e Religiosidades, vinculado

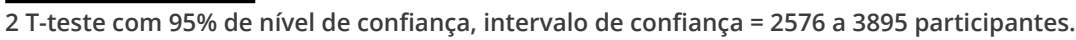


Expressões, características e perspectivas do Cristianismo da Libertação Fabio Lanza • Luis Gustavo Patrocino • Lenir Cândida de Assis

aos departamentos de Ciências Sociais, História e Serviço Social da Universidade Estadual de Londrina, estabeleceu um termo de parceria com o Secretariado do $14^{\circ}$ Intereclesial das $\mathrm{CEBs}^{3}$, o que permitiu a realização de ampla pesquisa documental (arquivos da organização), de observação participante e de campo com os participantes na edição de 2018.

As fontes principais da investigação foram os arquivos produzidos pela gestão do encontro e os dados coletados por meio de questionário aplicado aos sujeitos presentes no dia 24 de janeiro, primeiro dia de concentração na arena esportiva que sediou o encontro. $O$ universo dos instrumentos coletados na pesquisa de campo equivale a $68,62 \%$ dos participantes do encontro, o que significa dizer que dos 3114 participantes, 2137 responderam à pesquisa, número amostralmente suficiente para a produção de perfil, ainda que não seja censitário. Portanto, as informações relativas ao evento têm essa característica basilar e as afirmações realizadas no decorrer do texto sempre serão referentes ao horizonte de coleta.

Por causa da dinâmica do evento e da quantidade de pessoas, a decisão metodológica de coleta foi a de conseguir as informações através de um questionário de tipo survey, de autopreenchimento, contendo 22 perguntas cujas respostas foram tabuladas, posteriormente, para a produção do banco de dados. Devido ao local, não havia como garantir o não compartilhamento (isolamento) entre os entrevistados em relação às respostas. Ainda assim, a taxa de questionários preenchidos, 68,62\%, indica o sucesso da estratégia, uma vez que o ambiente e os objetivos dos entrevistados se alinhavam ao procedimento. Com relação ao perfil dos participantes, apresentamos alguns dados:

3 A partir da pesquisa eletrônica, para maiores informações acessar o site da própria organização: http://cebsdobrasil.com.br/ evento/14o-intereclesial-das-cebs-londrina-pr/. 
Expressões, características e perspectivas do Cristianismo da Libertação Fabio Lanza • Luis Gustavo Patrocino • Lenir Cândida de Assis

Figura 3 - Idade e Sexo dos participantes do $14^{\circ}$ Intereclesial

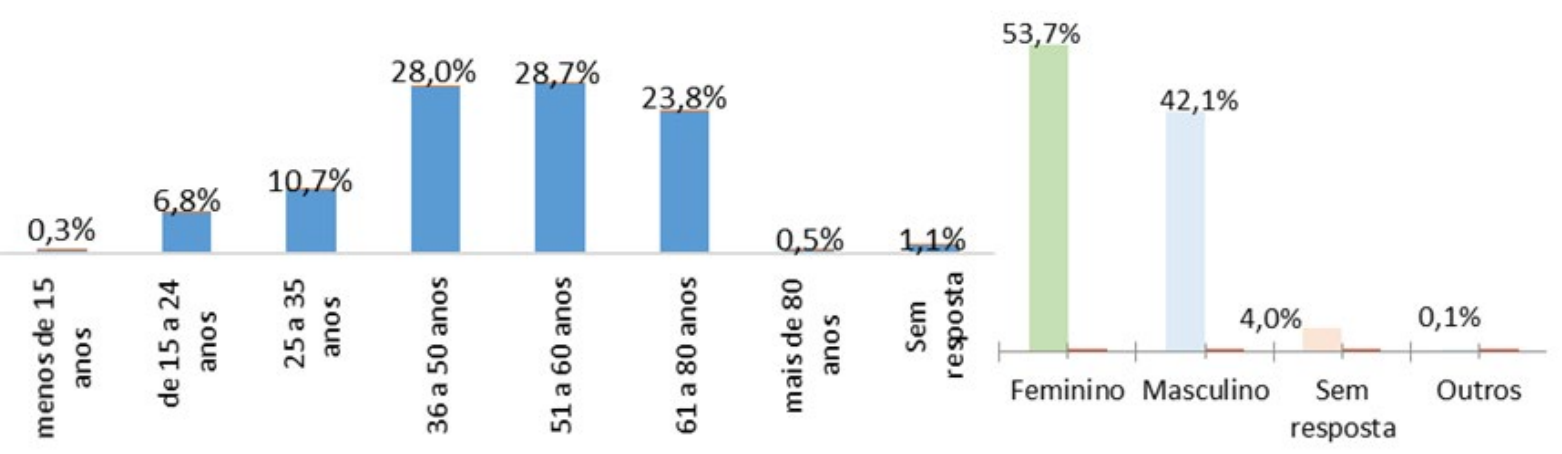

Fonte: Pesquisa sobre o 14 Intereclesial das CEBs em Londrina, PR (2018).

A Figura 3 expõe que a diferença etária é considerável entre as faixas definidas, $82,1 \%$ dos entrevistados tem mais de 36 anos. Essa informação vincula-se diretamente com a exposta na Figura 1, indicando que os membros das CEBs têm subsídios históricos para compreender e decidir sobre as ações propostas pelo movimento, fato possibilitador da perenidade das participações. No que concerne à variável sexo, nota-se uma pequena diferença entre as categorias masculino e feminino, o que é incomum nos ambientes religiosos, sabidamente de maioria feminina.

Também se destacam no perfil dos participantes suas condições econômicas e escolares. Na Figura 4, verificamos que 60,1\% tinham escolaridade além da Educação Básica nacional (Ensino Médio), número significante em um cenário de média de anos de estudo nacional de 9,3 anos (IBGE, 2018, p. 1). Ao mesmo tempo, é possível observar na distribuição etária da Figura 3, que o grupo agregado de 36 a 60 anos, representante de 56,7\% dos participantes, tem a Pós-graduação como Moda (item mais respondido) da escolaridade. 
Expressões, características e perspectivas do Cristianismo da Libertação Fabio Lanza • Luis Gustavo Patrocino • Lenir Cândida de Assis

Figura 4- Renda em salários mínimos e escolaridade dos participantes do $14^{\circ}$ Intereclesial

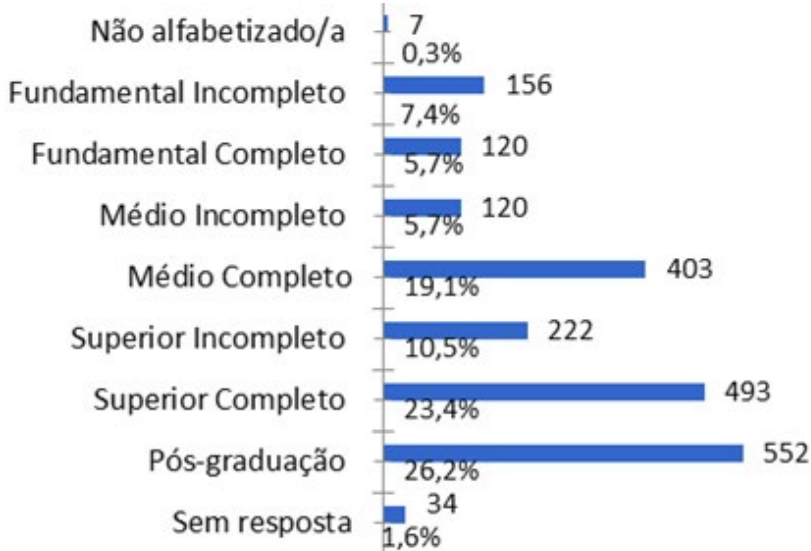

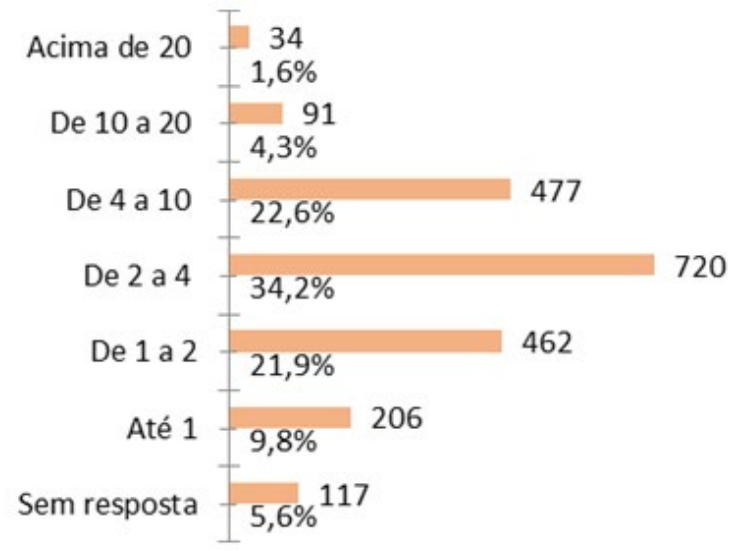

Fonte: Pesquisa sobre o $14^{\circ}$ Intereclesial das CEBs em Londrina, PR (2018). Nota: O salário mínimo vigente na época era de $R \$ 937,00$.

Ao somarmos as categorias Superior Completo e Pósgraduação, verificamos que o grupo composto por pessoas entre 25 e 60, representante de 67,4\% dos participantes, tem como Moda a condição de escolarização acima de Superior. Essa informação é relevante, pois não se trata de um evento destinado à liderança/ intelectualidade, mas a toda rede de indivíduos religiosos adeptos das ideias de devoção e ação política. Os representantes/delegados são membros das comunidades e paróquias, portanto esse dado expõe uma marca peculiar do grupo, pois contrastado com a realidade nacional mostra um hiato educacional relevante. 
Expressões, características e perspectivas do Cristianismo da Libertação Fabio Lanza • Luis Gustavo Patrocino • Lenir Cândida de Assis

\section{Figura 5 - Escolarização por faixas de idade dos participantes do $14^{\circ}$ encon- tro Intereclesial}

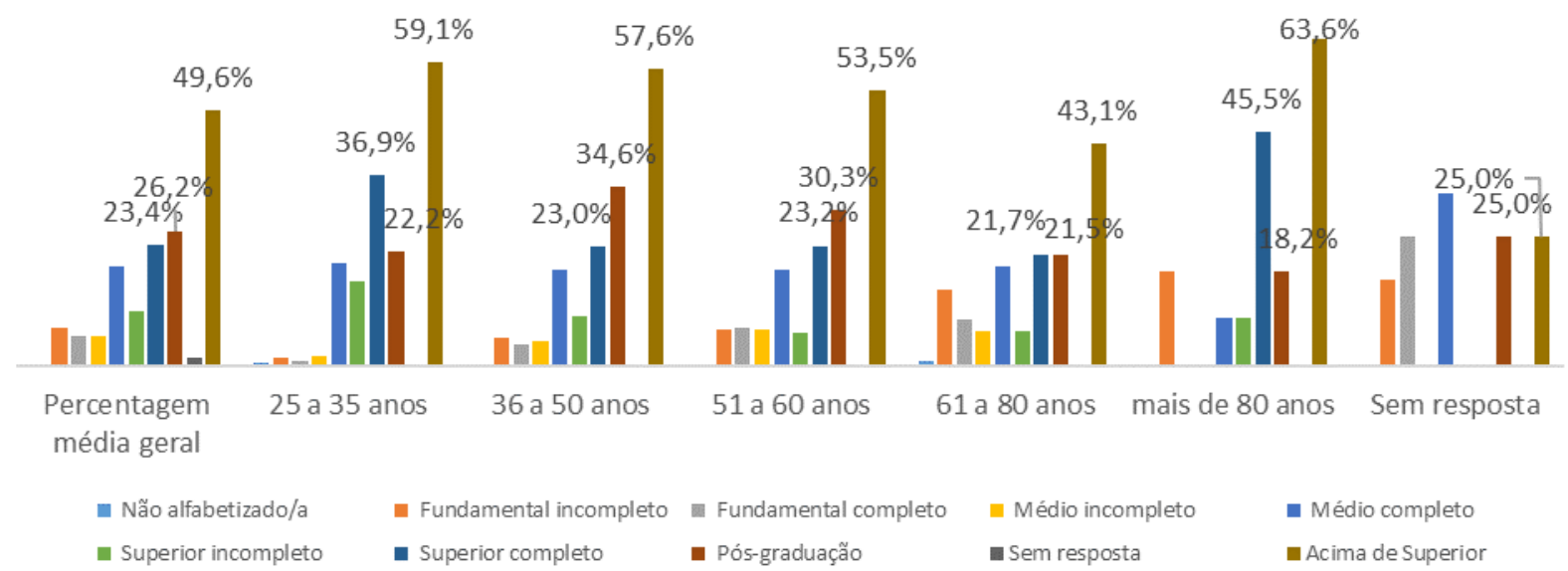

Fonte: Pesquisa sobre o $14^{\circ}$ Intereclesial das CEBs em Londrina, PR (2018).

Nota: A porcentagem média geral contém todas as faixas etárias. A categoria Acima de Superior foi criada a posteriori da coleta e soma as informações de escolaridades Superior Completa e Pós-graduação.

Quando observamos a Tabela 1 (abaixo) e contrastamos suas informações com as produzidas pelo Censo de 2010, recortando especificamente o Catolicismo, percebemos singularidades nos participantes das CEBs analisados. Nota-se, no que se refere à escolarização de ensino superior, um hiato de $56,1 \%$ entre o resultado nacional $(11,3 \%)$ e o do encontro $(67,4 \%)$. Também se destaca no contexto nacional a relação dos participantes e seus rendimentos. Sabe-se da associação direta existente no país (PNADC, 2017, p. 5) entre escolarização e rendimento, e nesse grupo a relação de dependência entre as variáveis não se alterou. 
Expressões, características e perspectivas do Cristianismo da Libertação Fabio Lanza • Luis Gustavo Patrocino • Lenir Cândida de Assis

Tabela 1- Escolarização e Religião no Censo de 2010, faixa etária acima de 25 anos

\begin{tabular}{l|c|c|c|c|c}
\hline & $\begin{array}{c}\text { Sem instrução } \\
\text { e fundamental } \\
\text { incompleto }\end{array}$ & $\begin{array}{c}\text { Fundamental } \\
\text { completo e } \\
\text { médio incom- } \\
\text { pleto }\end{array}$ & $\begin{array}{c}\text { Médio comple- } \\
\text { to e superior } \\
\text { incompleto }\end{array}$ & $\begin{array}{c}\text { Superior com- } \\
\text { pleto }\end{array}$ & $\begin{array}{c}\text { Não determi- } \\
\text { nado }\end{array}$ \\
\hline Católica & $51,2 \%$ & $14,0 \%$ & $23,2 \%$ & $11,3 \%$ & $0,2 \%$ \\
\hline Evangélica & $48,5 \%$ & $16,5 \%$ & $26,8 \%$ & $7,9 \%$ & $0,3 \%$ \\
\hline Espírita & $17,6 \%$ & $12,1 \%$ & $34,6 \%$ & $35,4 \%$ & $0,3 \%$ \\
\hline $\begin{array}{l}\text { Umbanda e } \\
\text { Candomblé }\end{array}$ & $32,6 \%$ & $18,4 \%$ & $33,5 \%$ & $15,3 \%$ & $0,4 \%$ \\
\hline $\begin{array}{l}\text { Outras reli- } \\
\text { giosidades }\end{array}$ & $39,5 \%$ & $16,1 \%$ & $29,5 \%$ & $14,5 \%$ & $0,4 \%$ \\
\hline Sem religião & $48,6 \%$ & $15,6 \%$ & $24,7 \%$ & $10,9 \%$ & $0,2 \%$ \\
\hline
\end{tabular}

Fonte: IBGE (2012)

Ainda assim, a variável renda tem uma faceta importante no conjunto de dados, ela foi coletada visando aos recursos daqueles que moravam com o entrevistado. A pergunta feita foi: "Qual o valor da renda somada de todos que moram com você?". Esse fato a vincula a outra variável do questionário, a que diz respeito às condições de domicílio. Também foi questionado quantas pessoas moravam com o entrevistado, ou seja, além do respondente, o domicílio era compartilhado com mais quantas pessoas.

Figura 6 - Quantas pessoas moram com você?

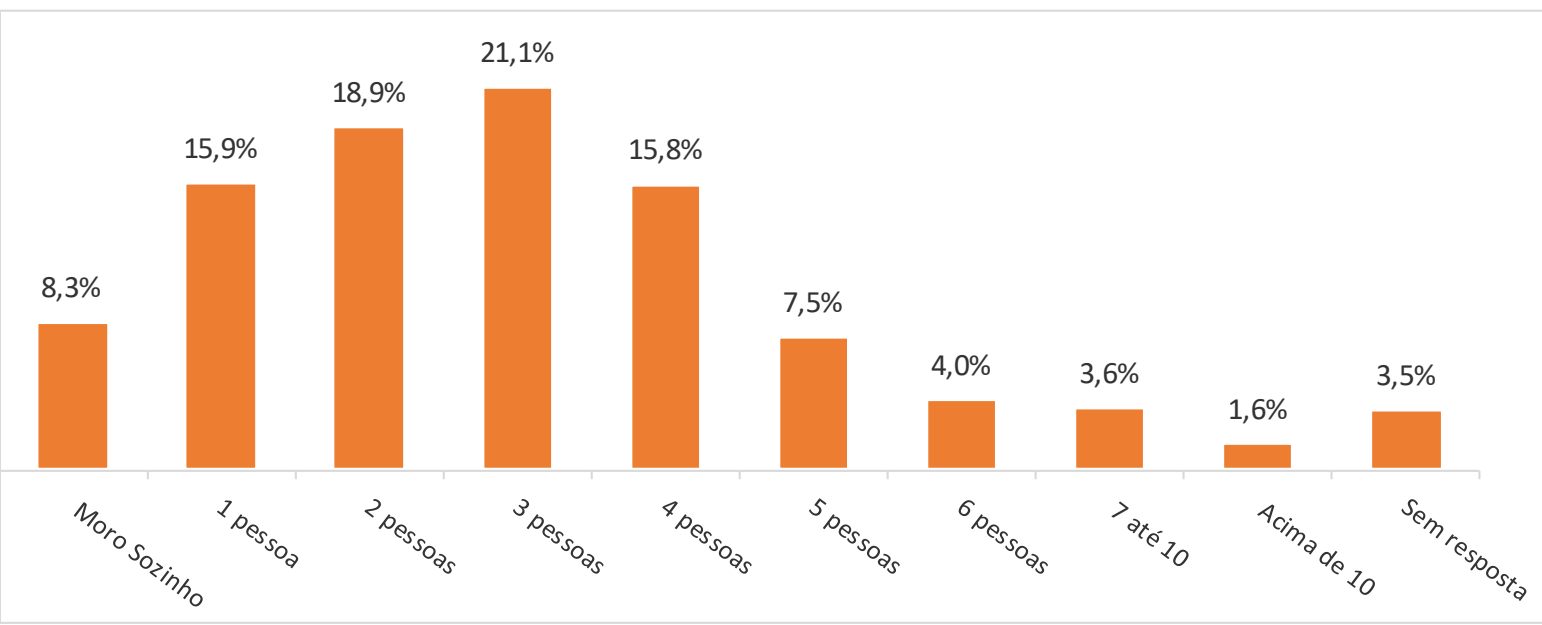

Fonte: Pesquisa sobre o $14^{\circ}$ Intereclesial das CEBs em Londrina, PR (2018).

4 IBGE. Tabela 1.4.9. In: Tabela Brasil. 2012. Disponível em: https://www.ibge.gov.br/estatisticas/sociais/populacao/9662-censo-demografico-2010.html?edicao=9749\&t=resultados. Acesso em: 28 jun. 2019. 
Expressões, características e perspectivas do Cristianismo da Libertação

No Brasil, a média de pessoas por domicílio é de 3 indivíduos (IBGE, 2012), contudo a Moda no evento foi de 4 pessoas $(21,1 \%)$. Percebe-se que a taxa de três habitantes por residência é baixa (18\%) e que as demais composições são inferiores à média nacional, fatos indicadores de uma perspectiva familiar mais extensa no número de membros.

No que concerne à distribuição das autodeclarações sobre cor/etnia, nota-se uma variação de 6,8\% com a realidade nacional na categoria branca. A pesquisa, porém, aprofundou a oferta de tipologia aos entrevistados, indo além do que é feito pelas investigações do IBGE (preta, parda), pois foi inserido na composição das opções de resposta o termo "negra". Essa ação visava identificar a opção do ponto de vista da luta política, isso porque trata-se de uma expressão oriunda de movimentos sociais reivindicatórios que enfrentam a questão racial brasileira e propõem a valorização da identidade do negro e da negra como estratégia de combate às expressões que identificam a cor da pele como parda, preta, não valorizando a ancestralidade africana no território brasileiro. Foram $17 \%$ dos entrevistados que se autodeclararam negros ou negras, mas as variáveis 'preta' e 'pardo' obtiveram, respectivamente, (4\%) e (32\%). Esses dados mostram que, somando pretos, pardos e negros, temos 53\%, índice superior à somatória nacional de pretos e pardos, que corresponde a $50 \%$ da população brasileira de católicos. 
Expressões, características e perspectivas do Cristianismo da Libertação Fabio Lanza • Luis Gustavo Patrocino • Lenir Cândida de Assis Figura 7 - Cor/raça dos participantes do $14^{\circ}$ encontro Intereclesial e Censo
2010

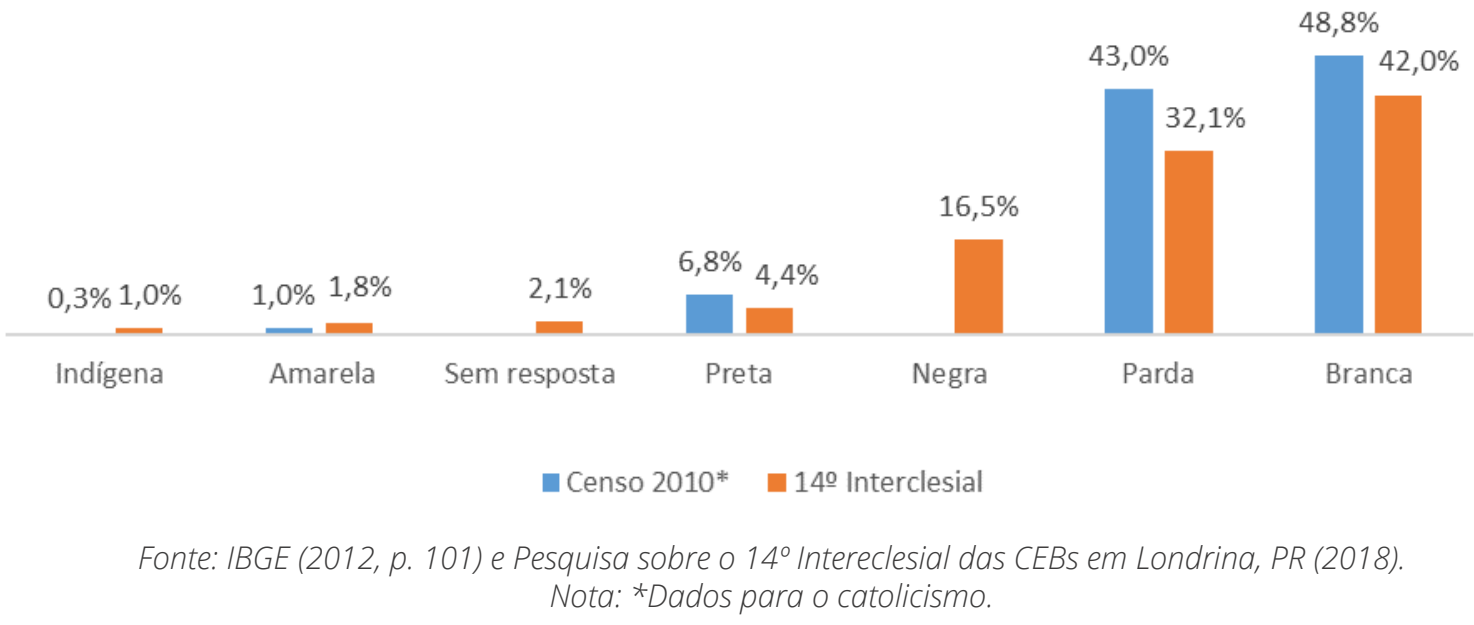

As características elencadas e correlacionadas aos dados do catolicismo nacional tencionam produzir o perfil desses participantes. Há outras variáveis e possibilidades de cruzamento. Neste texto objetivaram-se as questões mais comuns e suas descrições, de forma a ser possível perceber como a presença dos integrantes das CEBs apresenta-se, em média, no cenário religioso nacional.

\section{CEBs brasileiras: perspectiva progressista perante 0 conservadorismo}

Ao entender as características dos participantes do $14^{\circ}$ Intereclesial das CEBs, podemos dimensionar como esse grupo de cristãos, em sua maioria católicos, alinha-se com a perspectiva progressista (Figura 9) e utiliza os aspectos da conjuntura nacional e internacional para propor ações e estratégias no campo católico e cristão latino-americano. As reflexões, debates e encaminhamentos foram produzidos empregando a tríade do método5 "ver, julgar

\footnotetext{
5 Sobre o método, consta na Carta Encíclica Mater et Magistra de João XXIII, sob n. 235: “Para levar a realizações concretas dos princípios e das diretrizes sociais, passa-se ordinariamente por três fases: estudo da situação; apreciação da mesma à luz desses princípios e diretrizes; exame e determinação do que se pode e deve fazer para aplicar os princípios e as diretrizes à prática, segundo o modo e no grau que a situação permite ou reclama. São os três momentos que habitualmente se exprimem com as palavras seguintes: ver, julgar e agir".
} 
Expressões, características e perspectivas do Cristianismo da Libertação

Fabio Lanza • Luis Gustavo Patrocino • Lenir Cândida de Assis

e agir". O contexto mencionado está associado a uma estagnação decorrente da crise do capitalismo em esfera global:

Todos os faróis estão no vermelho: é evidente que a corrida louca atrás do lucro, a lógica produtivista e mercantil da civilização capitalista e industrial nos leva a um desastre ecológico de proporções incalculáveis. Não se trata de ceder ao "catastrofismo", mas, simplesmente, de constatar que a dinâmica do crescimento infinito, induzido pela expansão capitalista, ameaça destruir os fundamentos naturais da vida humana no Planeta.

De todos estes processos destrutivos, o mais óbvio, e perigoso, é o processo de mudança climática, um processo que resulta dos gases a efeito de estufa emitidos pela indústria, pelo agronegócio e pelo sistema de transporte existentes nas sociedades capitalistas modernas (LÖWY, 2013, p. 80 - grifos do autor).

Ao delimitarmos que a sociedade mundial enfrenta, sob o signo da globalização, a primeira crise que coloca todos (pessoas, regiões e países) no mesmo limbo diante de um horizonte sem perspectivas de que os problemas econômicos, sociais e ambientais (tanto no Oriente como no Ocidente) sejam resolvidos, podemos afirmar que novas perspectivas são produzidas (algumas reformuladas e outras resgatadas do passado distante) para se apresentarem como projetos de sociedade, que superem o contexto e a conjuntura caracterizados pela crise.

Atualmente há no país um forte debate a respeito da ascensão do conservadorismo ${ }^{6}$, quer na política parlamentar, quer no cotidiano. Nota-se nos discursos presentes em ambientes escolares, midiáticos e por redes sociais que há no mínimo um acirramento da questão na última década. Nesse contexto surge um elemento novo e interno da estrutura eclesiástica católica, o declínio do papado de Bento XVI e seu pedido de abdicação. Esse processo, que

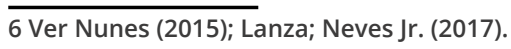


Expressões, características e perspectivas do Cristianismo da Libertação Fabio Lanza • Luis Gustavo Patrocino • Lenir Cândida de Assis

estava associado às próprias fissuras na estrutura do Vaticano, permitiu o acolhimento dos questionamentos ao status quo na gestão da própria Igreja Católica, bem como o fomento às estratégias alternativas da ação católica no mundo (contemporâneo e urbano). Isso nos faz indagar se ainda existem expressões do Cristianismo da Libertação na sociedade brasileira do século XXI.

Figura 9 - Aspectos necessários à atuação pastoral Católica segundo participantes do $14^{\circ}$ Intereclesial

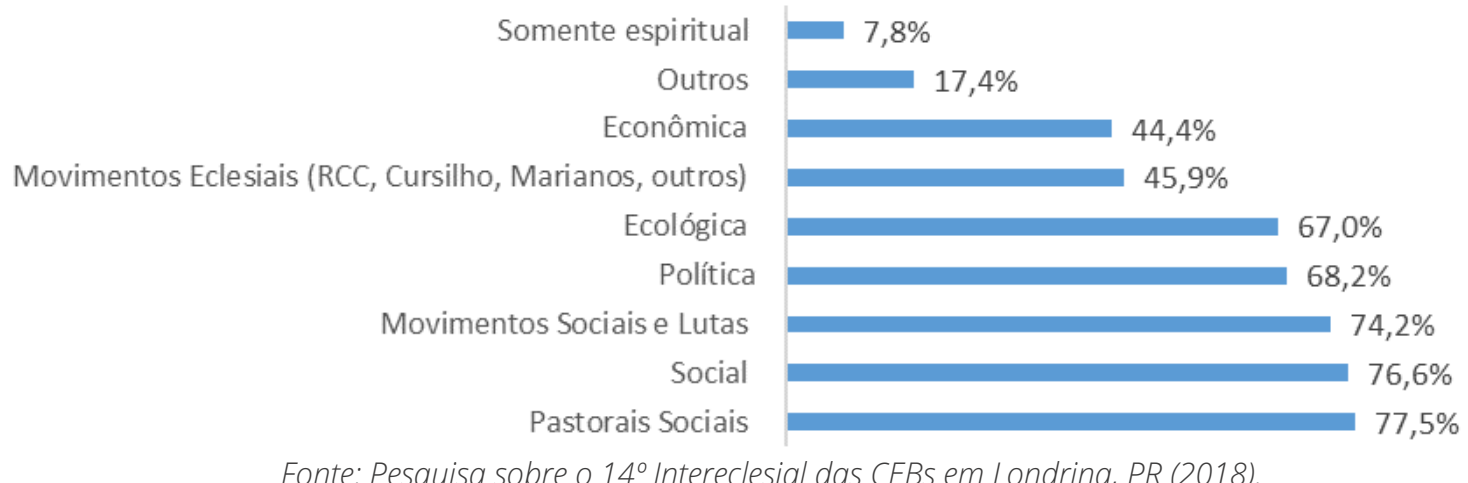

A questão posta nos remete diretamente à compreensão do que os participantes do $14^{\circ}$ Intereclesial expressam sobre a realidade do contexto em que vivem, sua capacidade de perceber e agir nas tramas da vida social. No instrumento de coleta de dados, incluíram-se duas indagações referentes a essa condição com o intuito de aferir se o movimento segue o fluxo religioso do cristianismo, orientado para a individualização e segmentação (HALL, 2011). As respostas à questão de múltipla escolha (Figura 9) nos permitem identificar que, para os membros das CEBs, as principais ações eclesiais deveriam estar ligadas diretamente a pautas cujos conteúdos são coletivos e passam, no presente modelo de estrutura de poder social, pela Política, diferentemente dos processos de individualização percebidos em outros movimentos do cristianismo, que se "fecham" para soluções personalizadas das instituições, tendo na Política um meio para impor/conquistar recursos das mais variadas espécies. A preocupação dos participantes se uniu a problemas de ordem macro, que são entraves para a ma- 
Expressões, características e perspectivas do Cristianismo da Libertação Fabio Lanza • Luis Gustavo Patrocino • Lenir Cândida de Assis

nutenção da vida cotidiana de todos os brasileiros, e ressoou os discursos do Vaticano na atualidade.

Essa concepção progressista no modo de pensar se alinha à encíclica do papa Francisco intitulada Laudato Si', publicada em 2015. A forma de conceber a realidade para além de propostas teleologicamente fixadas em assuntos estreitados à dogmática própria pautou uma agenda católica aberta, como uma carta e um apelo direcionados a todos os seres humanos, tal qual a encíclica:

Se a tendência actual se mantiver, este século poderá ser testemunha de mudanças climáticas inauditas e duma destruição sem precedentes dos ecossistemas, com graves consequências para todos nós. Por exemplo, a subida do nível do mar pode criar situações de extrema gravidade, se se considera que um quarto da população mundial vive à beira-mar ou muito perto dele, e a maior parte das megacidades estão situadas em áreas costeiras. As mudanças climáticas são um problema global com graves implicações ambientais, sociais, económicas, distributivas e políticas, constituindo actualmente um dos principais desafios para a humanidade. (FRANCISCO, 2015, p. 22).

Em seu discurso, o papa Francisco (2015) expõe, de maneira lúcida e pautado em contribuições científicas, a crise ambiental global. Toda humanidade sofrerá suas consequências, principalmente os pobres e os países em via de desenvolvimento.

Há vencedores e vencidos não só entre os países, mas também dentro dos países pobres, onde se devem identificar as diferentes responsabilidades. Por isso, as questões relacionadas com o meio ambiente e com o desenvolvimento económico já não se podem olhar apenas a partir das diferenças entre os países, mas exigem que se preste atenção às políticas nacionais e locais. (FRANCISCO, 2015, p. 135). 
Expressões, características e perspectivas do Cristianismo da Libertação Fabio Lanza • Luis Gustavo Patrocino • Lenir Cândida de Assis

Nesse sentido, podemos acrescentar que o ônus dessa conjuntura de crise capitalista-social-ambiental-econômica poderá ser custeado com a degradação ambiental e com a imposição de ris$\cos ^{7}$ às vidas humanas, com certo grau de irresponsabilidade considerando-se o contexto do século XXI. A perspectiva apresentada por Francisco compõe um possível quadro de "fissuras e rachaduras na parede" que faz a sustentação e manutenção do status quo. As críticas papais possuem ecos internos em sua própria Igreja ou externos, dadas as estruturas da sociedade capitalista global.

A envergadura imposta pelas crises e suas múltiplas facetas exige posicionamentos, também exige posturas públicas das lideranças religiosas, políticas e dos cidadãos em geral. Não se trata de uma reflexão metafísica, teológica ou de abordagens acadêmicas catastróficas. Os dados da realidade emergem e reforçam essa fundamentação: desastres ambientais nas barragens de mineração no Estado de Minas Gerais (Mariana, 2015; Brumadinho, 2019); impactos ambientais e sociais das Usinas Hidrelétricas (Belo Monte, PA, 2016; Balbina, AM, 1989); desastres ambientais com navios petroleiros desde o início do século XX; acidentes nucleares, Chernobyl (Ucrânia, 1986) e Fukushima (Japão, 2011); desabrigados ambientais devido à elevação do nível dos oceanos (destacadamente Tuvalu - país insular no oceano Pacífico) dentre outros. As reflexões a partir dos dados qualitativos extraídos da encíclica papal Laudato Si' reforçam que

\begin{abstract}
Neste contexto, sempre se deve recordar que «a protecção ambiental não pode ser assegurada somente com base no cálculo financeiro de custos e benefícios. O ambiente é um dos bens que os mecanismos de mercado não estão aptos a defender ou a promover adequadamente» ${ }^{8}$. Mais uma vez repito que convém evitar uma concepção mágica do mercado, que tende a pensar que os problemas se resolvem apenas com o crescimento dos lucros das empresas ou dos indivíduos. Será realista esperar que
\end{abstract}

\footnotetext{
7 Ver: Beck, U. A Sociedade de Risco: rumo a uma outra modernidade. Tradução de Sebastião Nascimento. São Paulo: Ed. 34, 2010.

8 [In: Pontifício Conselho «Justiça e Paz », Compêndio da Doutrina Social da Igreja, 470.]
} 
quem está obcecado com a maximização dos lucros se detenha a considerar os efeitos ambientais que deixará às próximas gerações? Dentro do esquema do ganho não há lugar para pensar nos ritmos da natureza, nos seus tempos de degradação e regeneração, e na complexidade dos ecossistemas que podem ser gravemente alterados pela intervenção humana. Além disso, quando se fala de biodiversidade, no máximo pensa-se nela como um reservatório de recursos económicos que poderia ser explorado, mas não se considera seriamente o valor real das coisas, o seu significado para as pessoas e as culturas, os interesses e as necessidades dos pobres. (FRANCISCO, 2015, p. 145).

Quando tratamos de questões da ecologia e do meio ambiente por vezes negligenciamos um aspecto do habitat humano: florestas, geleiras e mares, que são fundamentais para o clima e impactam diretamente o espaço onde os dramas sociais ocorrem, as cidades.

Nalguns lugares, rurais e urbanos, a privatização dos espaços tornou difícil o acesso dos cidadãos a áreas de especial beleza; noutros, criaram-se áreas residenciais «ecológicas» postas à disposição só de poucos, procurando-se evitar que outros entrem a perturbar uma tranquilidade artificial. Muitas vezes encontra-se uma cidade bela e cheia de espaços verdes e bem cuidados nalgumas áreas «seguras», mas não em áreas menos visíveis, onde vivem os descartados da sociedade. (FRANCISCO, 2015, p. 35).

Quem são os descartados da sociedade capitalista global? O que foi produzido pelo desenvolvimento urbano e/ou rural está para todos na sociedade global? Todos sabemos que os descartados são apresentados com várias formas e faces dentro dos contextos regionais e nacionais, mas temos, a partir da compreensão do recorte de classe social ou dos diversos estudos sobre as desigualdades sociais, que os descartados são parcela significativa 
Expressões, características e perspectivas do Cristianismo da Libertação Fabio Lanza • Luis Gustavo Patrocino • Lenir Cândida de Assis

ou então majoritária nas sociedades humanas distribuídas pelo globo. "Mas temos de nos convencer que reduzir um determinado ritmo de produção e consumo pode dar lugar a outra modalidade de progresso e desenvolvimento" (FRANCISCO, 2015, p. 146). Essa perspectiva está intimamente ligada aos dados e encaminhamentos produzidos pelo $14^{\circ}$ Intereclesial.

Figura 10 - População nos Censos Demográficos segundo as Grandes Regiões, as Unidades da Federação e a situação do domicílio - 1960/2010.

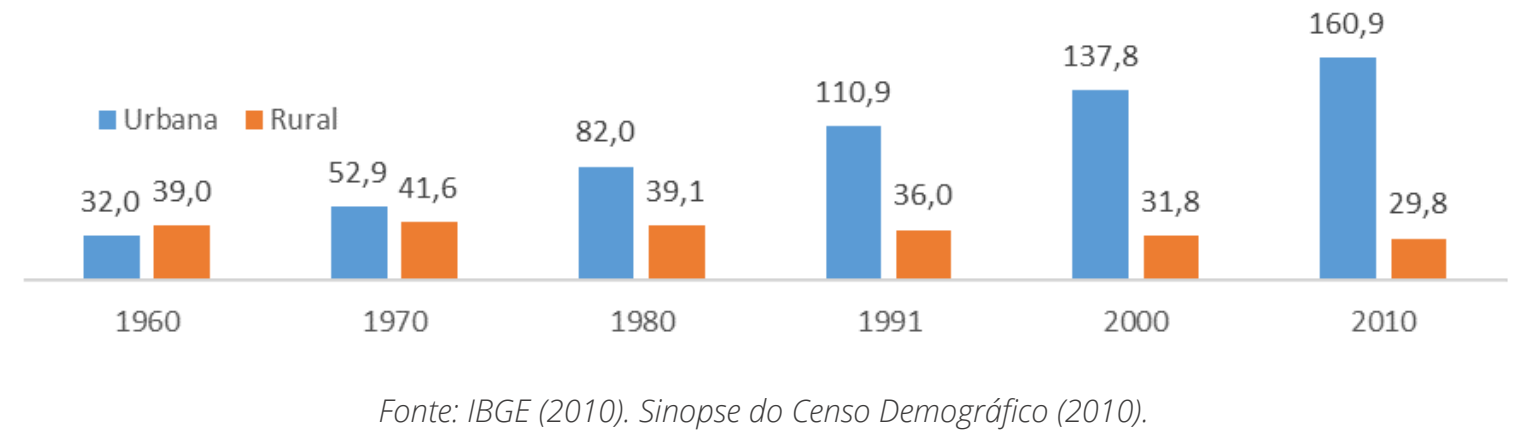

Uma referência importante no processo histórico que o País viveu a partir de meados do século XX, no momento de instauração das CEBs, foi a transição do campo para a cidade de grande contingente populacional. A Figura 10 nos mostra a inversão demográfica ocorrida no Brasil justamente na década de 1970. Essa pauta, unida aos desafios que a urbanização impõe cotidianamente, também expõe a mentalidade do movimento em relação a tempo e atuação. Na Figura 11, apresentamos quais eram as principais preocupações do grupo nesse quesito para fazer com que os participantes refletissem sobre as opções mais importantes da lista oferecida. Uma vez que todas são legítimas, limitamos a marcação a apenas três itens. 
Expressões, características e perspectivas do Cristianismo da Libertação

Fabio Lanza • Luis Gustavo Patrocino • Lenir Cândida de Assis

Figura 11 - Principais preocupações em relação ao mundo urbano segundo participantes do $14^{\circ}$ Intereclesial

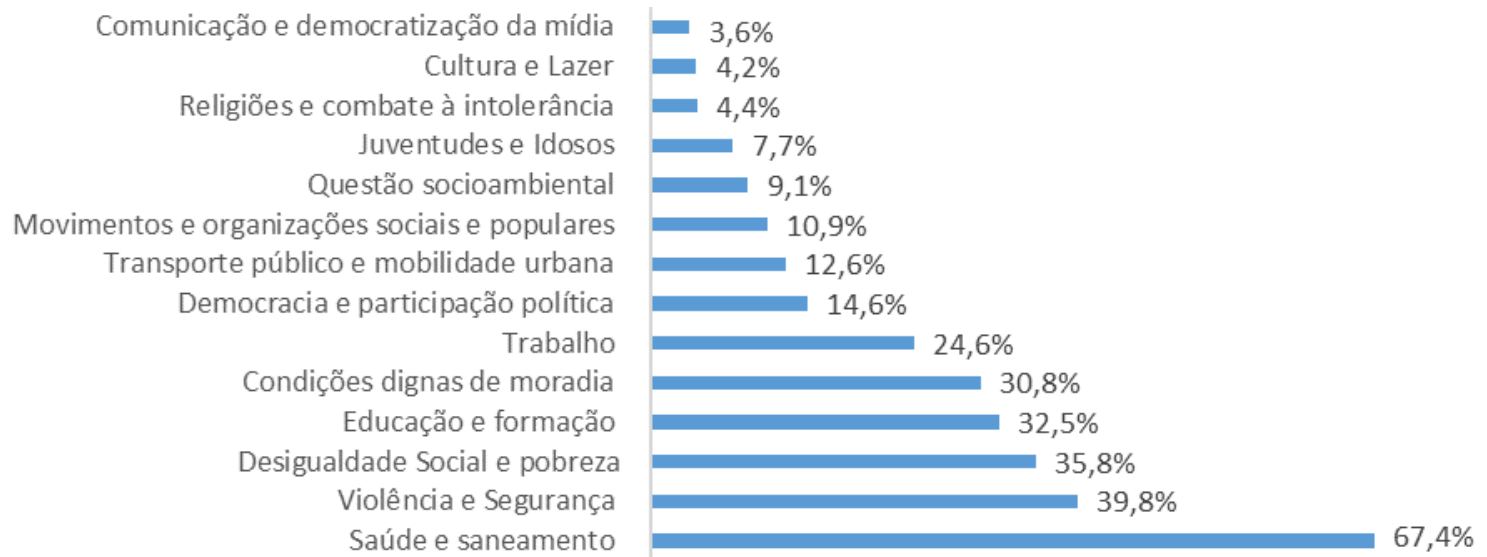

Fonte: Pesquisa sobre o $14^{\circ}$ Intereclesial das CEBs em Londrina, PR (2018).

Embora a renda apresentada pelos membros indique possibilidade de melhores condições de vida em relação à maioria da população nacional, os cinco itens que mais foram respondidos dizem respeito a problemas urbanos de infraestrutura básica. Excetuando o quarto, em ordem decrescente (Educação e formação), os demais se relacionam diretamente com habitação e espaço de convivência. Novamente percebemos que as respostas expressam a não adesão a uma moralidade que pensa exclusivamente a partir de sua própria condição socioeconômica.

$\mathrm{Na}$ atualidade, há uma emergência de críticas ao modo de produção e consumo, que se opõe ao avanço de grupos ou partidos conservadores e autoritários na Europa, Brasil e América Latina. Löwy sugere

[...] uma pista de reflexão: o sistema capitalista, sobretudo nos períodos de crise, produz e reproduz fenômenos como o fascismo, o racismo, os golpes de Estado e as ditaduras militares. A raiz desses fenômenos é sistêmica e a alternativa tem de ser radical, isto é, antissistêmica. Em vários países da América Latina está colocada a discussão sobre uma alternativa anti-imperialista e anticapitalista: o socialismo do século XXI. Isto é um socialismo 
que supera os limites dos movimentos socialistas do século passado - o compromisso social-democrata com o sistema e a degeneração burocrática do chamado "socialismo real" - mas recupera as bandeiras revolucionárias latino-americanas, de Simón Bolívar a Ernesto Che Guevara, de José Martí a Farabundo Martí, de Emiliano Zapata a Augusto César Sandino, de Zumbi dos Palmares a Chico Mendes. (LÖWY, 2015, p. 663).

Na conjuntura brasileira inaugurada com as manifestações de rua de 2013, houve inúmeras mobilizações sociais de perfil conservador que buscaram ascender ao poder político (legislativo e executivo). Uma das estratégias adotadas por esses grupos emergentes era fomentar discursos de ódio e perseguição a todos que se expressassem de maneira alternativa aos seus desejos e interesses. Esse acirramento de discussões conduziu o país a um "estado" de binarismo maniqueísta nos conteúdos políticos extremamente maléfico ao processo civilizador de formação política cidadã. As insistentes pautas jornalísticas e mensagens em aplicativos de comunicação tanto formaram quanto saturaram os indivíduos em relação às questões políticas. No "caos" produzido, uma das soluções que emergiram era a intervenção militar e a "caça aos comunistas" ou pessoas definidas por um dos grupos em disputa, como a esquerda. A partir desse ponto, no contexto pré-eleitoral de 2018 para a presidência da república, é possível entender como o Cristianismo da Libertação presente no $14^{\circ}$ Encontro Intereclesial das Comunidades Eclesiais de Base passou a ser alvo das ações de ódio e violência simbólica, bem como pôde ser caracterizado como alternativa ao status quo capitalista global. Vejamos, por exemplo, a perspectiva política dos participantes: 
Expressões, características e perspectivas do Cristianismo da Libertação Fabio Lanza • Luis Gustavo Patrocino • Lenir Cândida de Assis

Figura 12 - Melhor sistema político para o Brasil segundo participantes do $14^{\circ}$ Intereclesial

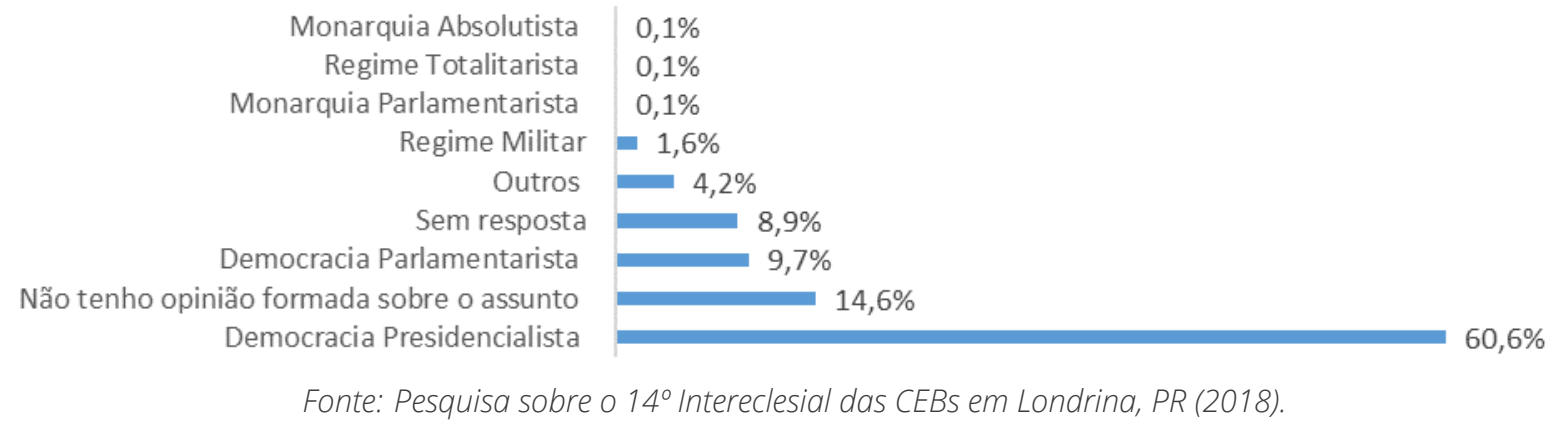

Percebe-se que, enquanto alguns grupos nacionais utilizavam até posturas rituais religiosas para expressarem sua devoção a sistemas de governo de tipo centralizador, como é o caso daqueles que pediam intervenção militar', os participantes do $14^{\circ}$ Intereclesial das CEBs indicam outra postura política em relação ao Estado: 70,3\% indicaram a democracia como melhor sistema mesmo dentro da conjuntura exposta. Contudo, é possível perceber seus ecos se somarmos aqueles que, de alguma forma, não responderam. Os "sem opinião formada" e "sem resposta" constituem $23,5 \%$ da amostra, ocupando o segundo lugar no ranqueamento das alternativas de resposta.

\section{Cristianismo e libertação do quê?}

As expressões e características dos participantes do $14^{\circ}$ Intereclesial das CEBs até aqui demonstradas e as reflexões expostas permitem problematizarmos: As propostas e os encaminhamentos do $14^{\circ}$ Intereclesial das CEBs estão alinhados com quais perspectivas no contexto brasileiro? Quais são as ações e encaminhamentos que os participantes buscam multiplicar pelo Brasil em suas comunidades?

9 Vide: O Bemdito (2018). 
Expressões, características e perspectivas do Cristianismo da Libertação Fabio Lanza • Luis Gustavo Patrocino • Lenir Cândida de Assis

O $14^{\circ}$ Intereclesial teve como tema Cebs e os desafios do mundo urbano. Um assunto que o papa Francisco aborda desde que assumiu o pontificado (2013), especialmente na defesa dos pobres. Segundo Tempesta (2018),

O Papa Francisco, além de ter significativamente escolhido esse nome por causa dos pobres, acentua que a opção preferencial pelos pobres não é uma categoria sociológica ou cultural, mas teológica, lembrando o que disse o Papa emérito Bento XVI na abertura da Conferência de Aparecida, de que esta opção está implícita na fé cristológica, de modo que não se pode seguir Jesus sem fazer esta opção e que ela deve perpassar transversalmente todas as estruturas e prioridades pastorais. (Evangelii Gaudium 198; cf. Documento de Aparecida 392; 396) [...] (Tempesta, 2018).

No decorrer do evento, treze pontos foram debatidos com a perspectiva de aprofundar estudos sobre as condições de vida a que estão submetidas as pessoas que vivem em todos os estados brasileiros. Situações existenciais que apontam os desafios do mundo urbano (tema central do evento) como condições de moradia, saúde e saneamento; mobilidade, educação e formação; cultura e lazer; participação político-partidária, trabalho, juventudes, ecologia, segurança e violência; comunicação e novas tecnologias; organizações sociais e populares e o diálogo inter-religioso ganharam destaque durante os cinco dias do evento. A pesquisa realizada pelo Laboratório de Estudos sobre Religiões e Religiosidades (LERR - UEL) buscou compreender como os participantes interagiram com esses desafios nas cidades e como estes se articulam com essa parte da Igreja Católica, que, apesar do avanço do conservadorismo em muitos setores, identifica-se como progressista e mantém a perspectiva que está na gênese da Teologia da Libertação.

O alinhamento dos participantes a uma perspectiva progressista fica evidenciado na pesquisa realizada e permite considerar, nesses agentes, uma diferenciação de ethos, tendo em vista que os 
Expressões, características e perspectivas do Cristianismo da Libertação Fabio Lanza • Luis Gustavo Patrocino • Lenir Cândida de Assis

sujeitos (executores do Cristianismo da Libertação) foram capazes de elaborar, ao longo do $14^{\circ}$ Intereclesial, uma leitura crítica a respeito da realidade conjuntural brasileira, em consonância com as propostas apontadas por Francisco (2015). Essa conjuntura está levando a população, especialmente os pobres e os trabalhadores que residem nas periferias das grandes cidades, a uma vida pautada na escassez, no desamparo público em relação a direitos sociais e infraestrutura mínima capaz de lhes garantir a possibilidade de sobrevivência, mesmo que precária.

A partir da pesquisa documental da encíclica Laudato Si,' o discurso do Papa Francisco indica que os processos de privatização dos bens ambientais poderá concentrar riqueza sob a forma privada e, ao mesmo tempo, impor escassez de acesso a grupos populacionais desassistidos pelos recursos hídricos e ou impedidos financeiramente de comprar água (FRANCISCO, 2015, p. 27).

Podemos considerar uma nova perspectiva em que a propriedade pública que cuida dos recursos hídricos sobrepõe-se aos interesses das empresas privadas que buscam lucros com a mercantilização da água? Se sim, há nessa perspectiva uma estratégia de superação da hegemonia da propriedade privada por outras formas de propriedade? Em tempo, sem que os sujeitos participantes do $14^{\circ}$ Intereclesial propusessem um processo revolucionário para suplantar a propriedade privada, eles destacam uma nova lógica em consonância com a ideia apresentada por Francisco (2015) e que ratifica as pesquisas de Elinor Ostrom, vencedora do Prêmio Nobel de Economia de 2009, com suas descobertas sobre recursos, bens e gestão de propriedade comum ${ }^{10}$.

Nesse sentido, evidenciamos que a produção epistemológica é debatida por Francisco em sua Encíclica. Ele afirmou que não há neutralidade no campo científico, portanto, nem no campo da política; fatos que são consonantes com a tomada de posição dos adeptos dos Cristianismos da Libertação.

$\overline{10 \text { Ver: Baiardi (2011). }}$ 
O que está a acontecer põe-nos perante a urgência de avançar numa corajosa revolução cultural. A ciência e a tecnologia não são neutrais, mas podem, desde o início até ao fim dum processo, envolver diferentes intenções e possibilidades que se podem configurar de várias maneiras. Ninguém quer o regresso à Idade da Pedra, mas é indispensável abrandar a marcha para olhar a realidade doutra forma, recolher os avanços positivos e sustentáveis e ao mesmo tempo recuperar os valores e os grandes objectivos arrasados por um desenfreamento megalómano. (FRANCISCO, 2015, p. 89-90).

Para Löwy (2013), é radical a necessidade de se discutir o capitalismo e a crise ambiental, bem como todas as demais questões envolvidas para viabilizar uma alternativa ecossocialista. Portanto, ele propõe uma superação da fragmentação analítica sobre a conjuntura da crise internacional (capitalista, global, política, ecológica, dentre outros campos) e uma ruptura com a perspectiva moderna, industrial, desenvolvimentista e pautada no prisma do progresso. Segundo o autor, “Uma reorganização do conjunto do modo de produção e de consumo é necessária, baseada em critérios exteriores ao mercado capitalista: as necessidades reais da população e a defesa do equilíbrio ecológico" (LÖWY, 2013, p. 83).

Um dos encaminhamentos feitos pelos participantes do Intereclesial foi a radicalização quanto à participação política de seus agentes na ocupação dos espaços de representação democrática popular. Há que se ressaltar o debate em torno da necessidade de novas lideranças capazes de fazer o enfrentamento a essas práticas geradas pelo capitalismo, lembrando que o Brasil ocupa o $9^{\circ}$ lugar ${ }^{11}$ no ranking dos países mais desiguais do mundo.

O problema é que não dispomos ainda da cultura necessária para enfrentar esta crise e há necessidade de construir lideranças que tracem caminhos, procurando dar resposta às necessidades das gerações actuais, todos incluídos, sem prejudicar as gerações

11 Disponível em: agenciabrasil.ebc.com.br/direitos-humanos/noticia/2018-11/renda-recua-e-Brasil-se-torna-o-9º-país-mais-desigual. Acesso em: jul. 2019. 
futuras. Torna-se indispensável criar um sistema normativo que inclua limites invioláveis e assegure a protecção dos ecossistemas, antes que as novas formas de poder derivadas do paradigma tecno-económico acabem por arrasá-los não só com a política, mas também com a liberdade e a justiça. (FRANCISCO, 2015, p. 43).

Segundo o Pontífice, enquanto não há uma cultura capaz de produzir lideranças ajustadas a essa proposta de mundo mais coletivo, as leis poderiam ser uma forma de romper o status quo, uma possibilidade de ruptura com a ordem vigente, que, aliadas ao "crescimento zero" e a "princípios de sustentabilidade", podem interromper a escalada da ideia de evolução e progresso que fundamenta os princípios de desenvolvimento capitalista nacional. O papa Francisco denuncia os malefícios causados pelos países ricos que se apropriam das riquezas naturais dos países pobres ou em desenvolvimento numa relação de subordinação e dependência, especialmente por conta das expressivas dívidas geradas com esse modelo de relação comercial/econômica que põe em risco a vida de toda uma nação.

A dívida externa dos países pobres transformou-se num instrumento de controle, mas não se dá o mesmo com a dívida ecológica. De várias maneiras os povos em vias de desenvolvimento, onde se encontram as reservas mais importantes da biosfera, continuam a alimentar o progresso dos países mais ricos à custa do seu presente e do seu futuro. A terra dos pobres do Sul é rica e pouco contaminada, mas o acesso à propriedade de bens e recursos para satisfazerem as suas carências vitais é Ihes vedado por um sistema de relações comerciais e de propriedade estruturalmente perverso. É necessário que os países desenvolvidos contribuam para resolver esta dívida, limitando significativamente o consumo de energia não renovável e fornecendo recursos aos países mais necessitados para promover políticas e programas de 
desenvolvimento sustentável. As regiões e os países mais pobres têm menos possibilidade de adoptar novos modelos de redução do impacto ambiental, porque não têm a preparação para desenvolver os processos necessários nem podem cobrir os seus custos. Por isso, deve-se manter claramente a consciência de que a mudança climática tem responsabilidades diversificadas e, como disseram os bispos dos Estados Unidos, é oportuno concentrar-se « especialmente sobre as necessidades dos pobres, fracos e vulneráveis, num debate muitas vezes dominado pelos interesses mais poderosos». É preciso vigorar a consciência de que somos uma única família humana. Não há fronteiras nem barreiras políticas ou sociais que permitam isolar-nos e, por isso mesmo, também não há espaço para a globalização da indiferença. (FRANCISCO, 2015, p. 42).

Leonardo Boff, um dos teólogos da Libertação e uma das vozes ouvidas pelos adeptos da TDL, afirmou que o discurso de Francisco (2015),

\begin{abstract}
Nasua ecologiaintegral, vêtodos osfatose fenômenosinterligados. Ofender a Terra é ofender o ser humano que também é Terra, como diz o Papa, citando o Gênesis. A voracidade produtivista e consumista produz duas injustiças, uma ecológica, degradando os ecossistemas, e outra social, lançando na pobreza e na miséria milhões de pessoas. O Papa denuncia essa conexão causal. Por isso propõe uma mudança de paradigma no relacionamento entre todos, que seja mais benevolente para com natureza e mais justo para com os seres humanos e todos os demais seres que habitam a casa comum. (BOFF, 2015).
\end{abstract}

Para Boff (2015), isso implica entender que a economia tem a ver com a política, a educação com a ética e a ética com a ciência. Todas as coisas relacionadas se entreajudam para existir, subsistir e continuar neste mundo. Essa visão é absolutamente nova nos discursos do magistério papal, ainda refém do paradigma que se- 
parava, dicotomizava, atomizava e dividia a realidade em compartimentos. Em função dessa visão distorcida, para cada problema havia a sua solução específica, sem se dar conta de sua incidência nas outras partes. A visão da ecologia integral é sistêmica, integra todas as coisas num grande todo dentro do qual nos movemos e somos. Seguindo a compreensão dessa relação que unifica, identificamos no $14^{\circ}$ encontro Intereclesial das CEBs a presença do movimento Cristianismo da Libertação que, em alguns momentos na história, mostra-se acuado, por vezes em declínio, mas nesta pesquisa foi identificado como ativo, com postura de resistência aos grupos considerados conservadores.

As propostas e encaminhamentos alinham-se aos anseios de parte da população pobre, das mulheres marginalizadas, dos negros, das juventudes, dos povos indígenas e quilombolas que não encontram lugar nas cidades e vivem à margem de uma sociedade que privilegia os interesses privados: a) a propriedade privada; b) a acumulação; uma inversão dos princípios éticos propagados pela ética cristã. Francisco (2015) faz uma defesa da ética social sobrepondo a propriedade privada:

[...] toda a abordagem ecológica deve integrar uma perspectiva social que tenha em conta os direitos fundamentais dos mais desfavorecidos. O princípio da subordinação da propriedade privada ao destino universal dos bens e, consequentemente, o direito universal ao seu uso é uma «regra de ouro» do comportamento social [...] A tradição cristã nunca reconheceu como absoluto ou intocável o direito à propriedade privada, e salientou a função social de qualquer forma de propriedade privada. (FRANCISCO, 2015, p. 73)

O papa Francisco ainda chama a atenção para as razões pelas quais esses povos das nações pobres vivem à margem da sociedade, na miséria, numa condição de fome, que não condiz com as perspectivas libertadoras dos cristianismos. 
Pretende-se, assim, legitimar o modelo distributivo actual, no qual uma minoria se julga com o direito de consumir numa proporção que seria impossível generalizar, porque o planeta não poderia sequer conter os resíduos de tal consumo. Além disso, sabemos que se desperdiça aproximadamente um terço dos alimentos produzidos, e « a comida que se desperdiça é como se fosse roubada da mesa do pobre ». Em todo o caso, é verdade que devemos prestar atenção ao desequilíbrio na distribuição da população pelo território, tanto a nível nacional como a nível mundial, porque o aumento do consumo levaria a situações regionais complexas pelas combinações de problemas ligados à poluição ambiental, ao transporte, ao tratamento de resíduos, à perda de recursos, à qualidade de vida (FRANCISCO, 2015, p. 39).

As Comunidades Eclesiais de Base, ao trazerem à luz as mazelas pelas quais passam a população brasileira e latino-americana (o empobrecimento, a criminalização, a opressão e os problemas ecológicos), despertam a atenção dos participantes para a necessidade urgente de produzir alternativas visando à libertação das pessoas por meio de novos modelos de desenvolvimento de produção, de consumo e de relacionamento capazes de promover uma nova economia, que, por sua vez, inserirá as pessoas nessa grande casa comum.

\begin{abstract}
Basta, porém, olhar a realidade com sinceridade, para ver que há uma grande deterioração da nossa casa comum. A esperança convida-nos a reconhecer que sempre há uma saída, sempre podemos mudar de rumo, sempre podemos fazer alguma coisa para resolver os problemas. Todavia parece notar-se sintomas dum ponto de ruptura, por causa da alta velocidade das mudanças e da degradação, que se manifestam tanto em catástrofes naturais regionais como em crises sociais ou mesmo financeiras, uma vez que os problemas do mundo não se podem analisar nem explicar de forma isolada. Há regiões que já se encontram particularmente em risco e, prescindindo
\end{abstract}


de qualquer previsão catastrófica, o certo é que o actual sistema mundial é insustentável a partir de vários pontos de vista. (FRANCISCO, 2015, p. 48).

Ao considerar os vários pontos de vista a que se refere o pontífice romano, os participantes do $14^{\circ}$ Intereclesial das CEBs elaboraram leituras relacionadas a situações nas cidades. Essa é uma postura que põe o status quo em questionamento e propõe outro tipo de sociedade? Se sim, isso indica que a maioria dos participantes tem consciência do processo histórico social econômico brasileiro que gerou a desigualdade social e que se manifesta na perspectiva de classe, renda, etnia, gênero e cultura.

O que revela, ainda, a compreensão da ausência de política pública de moradia nos municípios; da falta de investimento em transporte público de qualidade; das pequenas iniciativas de enfrentamento na destruição das riquezas naturais; do monopólio dos meios de comunicação gerado pela ausência de democratização; da alta taxa de desemprego enfrentado em todas as regiões do Brasil, sendo agravada pelas mudanças nas leis trabalhistas que flexibilizam direitos e precarizam o trabalho; da fragilidade do Brasil no que se refere à escola pública, que mantém o seu caráter excludente e não universalizante; das ameaças de perda dos direitos constituídos, levando a um processo de privatização do ensino; da ausência de investimento em saneamento básico e da precarização do Sistema único de Saúde e do alto índice de violência que se agrava no cotidiano da sociedade brasileira.

A invisibilidade da luta pela resistência dos movimentos sociais quilombolas e indígenas, a superexposição midiática da violência, que contribui para a insegurança sobretudo nas regiões mais periféricas, a ausência de políticas públicas para a juventude resultando em consequências danosas, como a depressão, o acesso a drogas, os homicídios, suicídios e o extermínio da juventude, especialmente da juventude negra e periférica. No caso dos jovens das periferias, eles vivem na invisibilidade para a sociedade e, quando tematizados, aparecem sempre como problemas e não como cidadãos detentores de direitos e sonhos. 
Os participantes do $14^{\circ}$ Intereclesial das Cebs, de forma conjunta, deliberaram por ações e encaminhamentos: apoiar os assentamentos rurais para que sejam produtivos e possam dar condições de fixação dos assentados no campo; lutar para que haja diversidade de meios alternativos de transportes nas cidades, considerando pedestres, bicicletas e outros; adequação específica de transporte e mobilidade para as realidades diversas (grandes metrópoles, comunidades no interior da Amazônia, meio rural, periferias); formação ou intensificação das escolas de Fé e Política e comitês da Cidadania, espaços privilegiados de formação e qualificação de pessoas para atuarem na ação política, nos partidos políticos, nos mecanismos de participação democrática; a agricultura familiar; ocupação dos espaços públicos ligados ao meio ambiente e à ecologia como forma de conhecê-los e preservá-los; participação na luta pelo direito a água; conscientização para o uso crítico dos meios de comunicação e democratização desses instrumentos; apoio à luta do(a)s trabalhadores(a)s da cidade e do campo; a agroecologia e a propagação da economia solidária.

Os encaminhamentos do $14^{\circ}$ Intereclesial aparentemente se alinham ao discurso do Papa, que defendeu sistemas alternativos de produção, porém fora da perspectiva da economia global agroexportadora:

Para se conseguir continuar a dar emprego, é indispensável promover uma economia que favoreça a diversificação produtiva e a criatividade empresarial. Por exemplo, há uma grande variedade de sistemas alimentares rurais de pequena escala que continuam a alimentar a maior parte da população mundial, utilizando uma porção reduzida de terreno e de água e produzindo menos resíduos, quer em pequenas parcelas agrícolas e hortas, quer na caça e recolha de produtos silvestres, quer na pesca artesanal. As economias de larga escala, especialmente no sector agrícola, acabam por forçar os pequenos agricultores a vender as suas terras ou a abandonar as suas culturas tradicionais. As tentativas feitas por alguns deles no sentido de desenvolverem 
Expressões, características e perspectivas do Cristianismo da Libertação Fabio Lanza • Luis Gustavo Patrocino • Lenir Cândida de Assis

outras formas de produção, mais diversificadas, resultam inúteis por causa da dificuldade de ter acesso aos mercados regionais e globais, ou porque a infraestrutura de venda e transporte está ao serviço das grandes empresas. (FRANCISCO, 2015, p. 100).

Na conjuntura atual e a partir do $14^{\circ}$ Intereclesial, qualificar lideranças para atuar na política, nos sindicatos, nos conselhos de políticas públicas, organizar grupos para acompanhar e fiscalizar a atuação dos eleitos nas esferas legislativa e executiva, além do apoio e participação popular nos movimentos sociais e sindicais, foram alguns dos encaminhamentos ligados à necessidade de formar novas lideranças políticas que assumam a gestão das cidades com o olhar voltado para a abertura de novas possibilidades para distribuição de riqueza, geração de trabalho, fim da miséria e da fome com vistas a uma sociedade do bem comum. O papa Francisco aponta a responsabilidade das autoridades políticas na condução das diversas esferas de poder.

As autoridades têm o direito e a responsabilidade de adoptar medidas de apoio claro e firme aos pequenos produtores e à diversificação da produção. Às vezes, para que haja uma liberdade económica da qual todos realmente beneficiem, pode ser necessário pôr limites àqueles que detêm maiores recursos e poder financeiro. A simples proclamação da liberdade económica, enquanto as condições reais impedem que muitos possam efectivamente ter acesso a ela e, ao mesmo tempo, se reduz o acesso ao trabalho, torna-se um discurso contraditório que desonra a política. A actividade empresarial, que é uma nobre vocação orientada para produzir riqueza e melhorar o mundo para todos, pode ser uma maneira muito fecunda de promover a região onde instala os seus empreendimentos, sobretudo se pensa que a criação de postos de trabalho é parte imprescindível do seu serviço ao bem comum". (FRANCISCO, 2015, p. 100). 
Expressões, características e perspectivas do Cristianismo da Libertação

Fabio Lanza • Luis Gustavo Patrocino • Lenir Cândida de Assis

É necessário indicar saídas para as crises existentes no mundo, crises socioambientais, climáticas, econômicas e políticas, itens pertencentes à mesma face de uma crise ética da humanidade.

\section{Considerações finais}

Para instigar a leitura e a curiosidade acadêmica, apontamos neste estudo que os adeptos dos Cristianismos da Libertação, que foram cerceados na luta interna da estrutura eclesial católica vinculada ao Vaticano no final do século XX e início do XXI, não foram colocados em extinção! Permanecem e se antagonizam ao conservadorismo de parte do clero e da sociedade brasileira. O declínio do papado de Bento XVI e as fissuras na estrutura do Vaticano permitiram o acolhimento dos questionamentos ao status quo, bem como o fomento das estratégias alternativas da ação católica em relação ao mundo (contemporâneo e urbano).

Os dados qualitativos da pesquisa documental utilizados nesta investigação tiveram como uma das fontes a Encíclica Papal Laudato Si' (FRANCISCO, 2015). Foi utilizada como fonte dos dados quantitativos a pesquisa realizada pelo LERR/UEL no primeiro dia de concentração dos participantes do $14^{\circ}$ Interereclesial das CEBs.

A pesquisa mostrou que o grupo analisado é altamente instruído, tanto em relação às condições gerais da população quanto ao próprio segmento religioso, o que tornou possível uma reflexão qualificada dentro da proposta do encontro que teve como tema as CEBs e os desafios do mundo urbano. As expressões, características e perspectivas dos Cristianismos da Libertação foram identificadas no perfil dos participantes do $14^{\circ}$ Intereclesial, mas, sobretudo, na capacidade de formular uma leitura crítica da realidade social, política, econômica e ambiental de uma sociedade submetida ao controle do capital, que gera exclusão e morte de pessoas e da vida planetária como nos aponta o papa Francisco na encíclica Laudato Si' (FRANCISCO, 2015). Destaca-se que os partici- 
pantes desse encontro não foram apenas os intelectuais das CEBs ou mesmo agentes "privilegiados", mas lideranças, principalmente leigas, de comunidades de base.

Nessa perspectiva, os encaminhamentos do encontro apontaram uma nova conjuntura que, por ora, apresentava-se no Brasil. Com a ruptura política em 2016, o Brasil caminhava para um cenário político certamente nefasto a pobres, trabalhadores e parcela populacional compreendida como minorias. Com o avanço do conservadorismo, contrário especialmente às pautas identitárias que impactam o cotidiano das pessoas, e que também se articulava dentro das plataformas políticas para fins eleitorais, os participantes do $14^{\circ}$ Intereclesial das CEBs sabiam que esse processo estaria fortemente organizado no interior da mesma Igreja.

Tendo em vista o contexto de janeiro de 2018 , os participantes das CEBs no $14^{\circ}$ Intereclesial, parcela progressista do catolicismo alinhada com a Teologia da Libertação, possuíam consciência da necessidade de reafirmarem a opção preferencial e histórica da Igreja latino-americana pelos pobres, com pautas que rumam à defesa de direitos, à denúncia profética contra os fatos que violam os Direitos Humanos (ONU-1948) e à preservação do planeta, segundo Francisco (2015), a casa comum.

Dessa forma, os dados coletados indicaram que há uma perspectiva política progressista dos participantes do $14^{\circ}$ Intereclesial (ou das CEBs) em relação ao contexto atual do século XXI no Brasil, indicando a adoção da democracia como regime balizador para o Estado brasileiro, adotando propostas de encaminhamentos com ênfase no coletivo e no social, rompendo as outras bandeiras de grupos cristãos individualizantes e neoliberais.

A partir da observação de campo no $14^{\circ}$ Intereclesial e do discurso de Francisco (2015), identificamos uma posição antagônica em relação aos grupos adeptos de ideias autoritárias e antidemocráticas, porque nem o Papa ou cristãos da libertação acreditam ou defendem a falácia da neutralidade nas crises atuais ou no campo científico. 
Foi possível identificar também, a partir dos dados quanti-qualitativos coletados no $14^{\circ}$ Intereclesial, que as CEBs do Brasil têm uma extensa pauta a cumprir, cujo objetivo é multiplicar, nas diversas regiões brasileiras, as propostas que foram ali construídas, alinhadas à atual conjuntura política, social, econômica, ambiental e eclesial em consonância com a Encíclica do papa Francisco (2015). Tais encaminhamentos extrapolam os enfrentamentos internos necessários para garantir uma Igreja dos pobres, mas, de forma especial, vão ao encontro da urgência das ações civis dos católicos presentes nos mecanismos de participação democrática e popular, na luta pela justiça, na defesa dos direitos e na garantia do acesso a cidades, com políticas públicas de qualidade e o restabelecimento das garantias constitucionais tão ameaçadas pelos interesses do capital (nacional ou internacional).

\section{Referências}

BAIARDI, Amilcar. Elinor Ostrom, a premiação da visão unificada das ciências humanas. Caderno CRH, Salvador, v. 24, n. 61, Jan./Abr. 2011, p. 203-216.

BOFF, Leonardo. Ecologia integral. A grande novidade da Laudato Si'. “Nem a ONU produziu um texto desta natureza". Entrevista especial com Leonardo Boff. 2015. Disponível em: http://www.ihu.unisinos. br/entrevistas/543662-ecologia-integral-a-grande-novidade-da-laudato-si-qnem-a-onu-produziu-um-texto-desta-natureza-entrevista-especial-com-leonardo-boff. Acesso em: 18 jun. 2019.

CNBB. Memória dos primeiros 13 encontros intereclesiais das CEBs no Brasil. Brasília: 2018. Disponível em: http://www.cnbb.org.br/memoria-dos-primeiros-13-encontros-intereclesiais-das-cebs-no-brasil/. 2018. Acesso em: 25 jun. 2018.

FRANCISCO, Papa. Encíclica Laudato Si'. Disponível em: http://www. paroquias-sintra.pt/actualidade/enciclica-do-papa-francisco-lauda- 
Expressões, características e perspectivas do Cristianismo da Libertação Fabio Lanza • Luis Gustavo Patrocino • Lenir Cândida de Assis

to-si-sobre-o-cuidado-da-casa-comum. Vaticano: 2015. Acesso em: 28 jun. 2019.

HALL, Stuart. A identidade Cultural na Pós-modernidade. 11 ed. Rio de Janeiro: DP\&A, 2011.

IBGE 2010. Sinopse do Censo Demográfico 2010. Disponível em: https://censo2010.ibge.gov.br/sinopse/index.php?dados $=8 \& u f=00$. Acesso em: 28 jun. 2019

IBGE. PNAD Contínua: Educação 2018. Disponível em: https://biblioteca.ibge.gov.br/visualizacao/livros/liv101657_informativo.pdf> Acesso em: 27 jun. 2019

IBGE. Censo demográfico 2010: características gerais da população, religião e pessoa com deficiência. Rio de Janeiro. Disponível em: https:// biblioteca.ibge.gov.br/visualizacao/periodicos/94/cd_2010_religiao_deficiencia.pdf. Acesso em: 28 jun. 2019

IBGE. Pesquisa Nacional por amostra de domicílios contínua. 2017. Rendimento de todas as fontes 2017. Disponível em: https://biblioteca. ibge.gov.br/visualizacao/livros/liv101559_informativo.pdf

JOÃO XXIII. Carta Encíclica Mater et Magistra. 1961. Disponível em: http://w2.vatican.va/content/john-xxiii/pt/encyclicals/documents/hf_jxxiii_enc_15051961_mater.html. Acesso em: 9 jul. 2019.

LANZA, Fabio; NEVES JÚNIOR, José Wilson Assis. Expressões do novo intervencionismo: uma análise do grupo conservador 'Ordem Dourada do Brasil'. Estudos de Sociologia, v. 22, p. 35-51, 2017.

LÖWY, Michael. Conservadorismo e extrema-direita na Europa e no Brasil. Serv. Soc. Soc., São Paulo, n. 124, p. 652-664, out./dez. 2015. LÖWY, Michael. Crise ecológica, crise capitalista, crise de civilização: a alternativa ecossocialista. Caderno CRH. Salvador, v. 26, 67, p. 79-86, Jan./Abr. 2013.

LÖWY, Michael. O Catolicismo Latino-Americano Radicalizado. Estudos Avançados, São Paulo, IEA-USP, v. 3, n. 5, p. 50-9, jan./abr.1989. 
Expressões, características e perspectivas do Cristianismo da Libertação Fabio Lanza • Luis Gustavo Patrocino • Lenir Cândida de Assis

NERI, Marcelo. Novo Mapa das Religiões. Rio de Janeiro: FGV 2011. Disponível em: https://www.cps.fgv.br/cps/bd/rel3/REN_texto_FGV_ CPS_Neri.pdf. Acesso em: 27 jun. 2019.

NUNES. Rodrigo. A 'onda conservadora' é menos fácil de entender do que se imagina. 2015. Disponível em: https://www1.folha.uol. com.br/ilustrissima/2015/08/1674857-ascensao-conservadora-e-complexo-de-katechon.shtml. Acesso em: 27 set. 2019.

\section{O BEMDITO. Manifestantes se ajoelham em frente ao Exército e} clamam por intervenção militar. 2018. Disponível em: http://www. obemdito.com.br/regiao/manifestantes-se-ajoelham-em-frente-ao-exercito-e-clamam-por/17693/. Acesso em: 1 jun. 2019.

TEMPESTA. Cardeal Orani João. Proximidade dos mais pobres. CNBB. 2018. Disponível em: http://www.cnbb.org.br/proximidade-dos-mais-pobres/. Acesso em: 09 jul. 2019. 